This document is the Accepted Manuscript version of a Published Work that appeared in final form in:

García de Jalón S., González del Tánago M., García de Jalón D. 2019. A new approach for assessing natural patterns of flow variability and hydrological alterations: The case of the Spanish rivers. JOURNAL OF ENVIRONMENTAL MANAGEMENT. 233. 200-210. DOI (10.1016/j.jenvman.2018.12.049).

(c) 2018 Elsevier Ltd

This manuscript version is made available under the CC-BY-NC-ND 3.0 license http://creativecommons.org/licenses/by-nc-nd/3.0/

\title{
A new approach for assessing natural patterns of flow variability and hydrological alterations: the case of the Spanish rivers
}

Silvestre García de Jalón ${ }^{1 *}$, Marta González del Tánago², Diego García de Jalón²

(1) Basque Centre for Climate Change - BC3. Building 1, 1st floor, Scientific Campus of the University of the Basque Country. Barrio Sarriena, s/n | 48940 Leioa, Bizkaia, Spain.

(2) Department of Natural Resources and Systems, Universidad Politécnica de Madrid, E.T.S.I. Montes, Forestal y del Medio Natural, 28040, Madrid, Spain.

$(*)$ Corresponding author. E-mail: silvestre.garciadejalon@bc3research.org.

\section{Abstract}

Ensuring water is available for human use usually requires dams and reservoirs that severely affect river ecosystems. Hydrological alteration by river damming represents one of the most prominent human impacts on freshwater ecosystems. This paper presents a methodological approach to assessing the natural patterns of flow variability and hydrological alterations in Mediterranean rivers. The methodology first defines the admissible range of flow variability under a natural flow regime. Then, the methodology measures the environmental impact of flow regulation according to the inferred hydrological alteration and classifies rivers into homogeneous groups according to the magnitude, frequency, duration and seasonality of the impacts. This paper applies the proposed methodology to thirty-three river segments below large reservoirs located in the three largest Spanish watersheds (Duero, Ebro and Tajo). For each segment, this study evaluates the general impoundment characteristics and geographical contexts and calculates the flow impacts and the divergence between the circulating flows and the reference area of admissible flow variability on a daily basis for the period 2000-2010. This assessment of dam regulation impacts provides a reference to plan measures for mitigating these impacts. The advantages of this flow regulation impact analysis over other analyses are discussed in terms of the implementation of environmental water costs as suggested by the European Water Framework Directive. This approach expands the 
This document is the Accepted Manuscript version of a Published Work that appeared in final form in:

García de Jalón S., González del Tánago M., García de Jalón D. 2019. A new approach for assessing natural patterns of flow variability and hydrological alterations: The case of the Spanish rivers. JOURNAL OF ENVIRONMENTAL MANAGEMENT. 233. 200-210. DOI (10.1016/j.jenvman.2018.12.049).

(C) 2018 Elsevier Ltd

This manuscript version is made available under the CC-BY-NC-ND 3.0 license http://creativecommons.org/licenses/by-nc-nd/3.0/

current understanding of water environmental costs and represents a practical management tool for decreasing the environmental impacts of flow regulation and for increasing water-use efficiency.

\section{Keywords:}

Flow regulation; Hydrological impacts; Environmental costs; Dams; Water Framework Directive; Mediterranean 
This document is the Accepted Manuscript version of a Published Work that appeared in final form in:

García de Jalón S., González del Tánago M., García de Jalón D. 2019. A new approach for assessing natural patterns of flow variability and hydrological alterations: The case of the Spanish rivers. JOURNAL OF ENVIRONMENTAL MANAGEMENT. 233. 200-210. DOI (10.1016/j.jenvman.2018.12.049).

\section{(c) 2018 Elsevier Ltd}

This manuscript version is made available under the CC-BY-NC-ND 3.0 license http://creativecommons.org/licenses/by-nc-nd/3.0/

\section{Introduction}

Hydrological alteration due to river damming represents a worldwide environmental impact that seriously modifies the magnitude and timing of natural flow regimes and threatens the biodiversity of fluvial ecosystems at the global scale (Poff et al., 2007; Döll et al., 2009). In Mediterranean regions, river damming has long been used to cope with the natural seasonality of precipitation (Hooke, 2006). In these regions, precipitation and runoff are out of phase with water demand, and rivers tend to be more heavily impounded than rivers in humid regions, resulting in artificially reduced flood peaks and increased summer base flows (Kondolf and Batalla, 2005; Grantham et al., 2013). Strong reductions in discharge and significant spatial and temporal extension of nonperennial streams have been observed in many Mediterranean basins because of intensive regulation of natural flows (Ludwig et al., 2009; Skoulikidis et al., 2017). In Spain, flow regulation has intensified during the second half of the last century, when more than 1,300 large dams were constructed (MMA, 2006), inducing serious changes in the magnitude of flows and reversals of natural seasonal patterns in the rivers (Batalla et al., 2004; Grindlay et al., 2011; Lorenzo-Lacruz et al., 2012).

The environmental effects of flow regulation in river ecosystems, and more particularly in Mediterranean streams, have been widely reported (e.g., Kondolf and Batalla, 2005; Hooke, 2006; González del Tánago et al., 2015). Water stored in Mediterranean reservoirs is primarily used for irrigation, resulting in a reduction in winter flows when dams store water and an increase of summer flows when dams release water for crop irrigation (Kondolf and Batalla, 2005). Inadequate circulating flows downstream from dams commonly amplify the effects of a variety of other stressors occurring in Mediterranean basins, such as intensive water abstraction, pollution and reduction of river runoff due to climate change (Vörösmarty et al., 2010; Skoulikidis et al., 2017). In general, artificial alterations of flow regimes affect the health and sustainability of river communities. River damming has led to fragmentation of most rivers that flow into the Mediterranean Sea (Tockner et al., 2009). Major declines in native fish diversity in many Spanish rivers have resulted from habitat alteration by dam construction (Aparicio et al., 2000). Furthermore, the reduction in hydrological variability and sediment supply downstream from dams has changed the geomorphic patterns of rivers and encouraged vegetation encroachment that inhibits the natural dynamic succession of riparian zones (González del Tánago et al., 2015; Lobera et al., 2015). 
This document is the Accepted Manuscript version of a Published Work that appeared in final form in:

García de Jalón S., González del Tánago M., García de Jalón D. 2019. A new approach for assessing natural patterns of flow variability and hydrological alterations: The case of the Spanish rivers. JOURNAL OF ENVIRONMENTAL MANAGEMENT. 233. 200-210. DOI (10.1016/j.jenvman.2018.12.049).

\section{(C) 2018 Elsevier Ltd}

This manuscript version is made available under the CC-BY-NC-ND 3.0 license http://creativecommons.org/licenses/by-nc-nd/3.0/

While the ecological and geomorphic effects of flow regulation have been extensively documented (e.g., Poff and Zimmerman, 2010), much less research has directly measured the hydrological effects of dams and reservoirs in quantitative terms. Magilligan and Nislow (2005) and McManamay (2014) evaluated hydrological shifts in impounded rivers covering a wide spectrum of flow regulation across the United States, highlighting the significant changes that occurred in minimum and maximum flows over different durations. In general, dams are hypothesized to homogenize flows across distinct biogeographic regions (Poff et al., 2010), but alterations in the seasonal magnitude, duration, frequency and timing of flows seem to be site specific and depend on not only the dam operation but also the regional hydrological context (McManamay et al., 2012).

The loss of hydrologic variability in rivers due to dam operations is one of the major environmental effects of dams and leads to a loss of habitat variability, homogenization of river fauna and a significant decrease in biodiversity (Moyle and Mount, 2007; Poff et al., 2007). Flow variability is one of the main drivers of ecosystem processes (Cid et al., 2017) and has an essential role in the interplay of river structure, physical processes and ecological patterns (Naiman et al., 2008; Wohl, 2012). Releasing spring spawning flows for fish communities (Marchetti and Moyle, 2001) or seasonally appropriate high and low flows for successful recruitment of riparian species (Mahoney and Rood, 1998; Hall et al., 2009; Stromberg et al., 2010) requires prior knowledge of the natural patterns of flow variability to which native species are adapted. Thus, identifying the general trends of natural flow variability and seasonality in each basin is essential to delineating environmental flows that preserve the health of river ecosystems.

The natural flow regime paradigm has been widely accepted as the most useful model for defining the variability in functional flows and for estimating year-round sustainable water withdrawals (Poff et al., 1997; Richter et al., 2012; Yarnell et al., 2015). Many authors (Landres et al., 1999; Keane et al., 2009) have extended this paradigm to the management of ecosystems in a manner consistent with their natural functioning using the historical range of variability as a benchmark or reference to represent natural conditions.

Moreover, the implementation of the European Water Framework Directive (WFD) (EC, European Commission, 2000) has introduced new concepts and procedures for river management and EU water policy. Following WFD rules, current flow conditions must be assessed in relation to theoretical reference conditions, and the managed flow of regulated rivers within a paradigm of maintaining the ecology of rivers systems should be derived from the natural flow regimes (Poff et 
This document is the Accepted Manuscript version of a Published Work that appeared in final form in:

García de Jalón S., González del Tánago M., García de Jalón D. 2019. A new approach for assessing natural patterns of flow variability and hydrological alterations: The case of the Spanish rivers. JOURNAL OF ENVIRONMENTAL MANAGEMENT. 233. 200-210. DOI (10.1016/j.jenvman.2018.12.049).

\section{(c) 2018 Elsevier Ltd}

This manuscript version is made available under the CC-BY-NC-ND 3.0 license http://creativecommons.org/licenses/by-nc-nd/3.0/

al., 1997; Bunn and Arthington, 2002). Additionally, the WFD requires an economic analysis of water use and encourages the recovery of the full costs of water use to foster a more environmentally sensitive water policy across the EU countries (WATECO, 2003). Water costs include the 'environmental costs', which are defined as the costs of damage that water use imposes on the environment and ecosystems. Thus, fulfilling the requirements of the WFD requires new approaches to assessing the relation of current flow conditions to natural flow regimes that are aligned with new methods that link hydrological alterations with environmental costs. The economic aspects of flow regulation impacts have traditionally been less important or partially hindered by social factors (e.g., Bithas, 2008), but in the context of the WFD, they have to be highlighted and included in the decision-making processes of water-use planning (Cooper et al., 2014).

In this context, it is worth exploring the degree and patterns of flow regulation in Mediterranean rivers and inferring the major natural (e.g., climatic conditions) and anthropogenic (e.g., land use, water demands) factors that contribute to the intensity of flow regulation, its environmental impact and its potential environmental costs. To achieve these goals, this paper has elucidated general patterns of natural flow variability and evaluated the hydrological impact of flow regulation in the main river basins of Central and Northern Spain. The methodology proposes a novel approach for assessing the hydrologic impact of flow regulation (i.e., deviation from the natural flow regime), which could be subsequently used to estimate potential environmental costs.

This study has two major objectives. The first objective involves quantifying the hydrologic impact of flow regulation in Spain using flow data from the main Iberian river basins. In this case, we aimed to explore general patterns of flow regulation impacts in Mediterranean regions by analysing the degree of regulation (i.e., deviation from the natural flow regime) with respect to natural flow regime drivers (e.g., climatic conditions) and major human water uses (e.g., irrigation demands). The second objective involves applying the methodology of the hydrological impact assessment previously proposed by García de Jalón et al. (2017a) to 1) identify regional patterns in natural flow variability as a scientific basis for environmental flow design and 2) to quantify hydrological impacts across different geographical contexts to support further economic analyses, specifically in the appraisal of the environmental costs of flow regulation by dams and reservoirs. 
This document is the Accepted Manuscript version of a Published Work that appeared in final form in:

García de Jalón S., González del Tánago M., García de Jalón D. 2019. A new approach for assessing natural patterns of flow variability and hydrological alterations: The case of the Spanish rivers. JOURNAL OF ENVIRONMENTAL MANAGEMENT. 233. 200-210. DOI (10.1016/j.jenvman.2018.12.049).

(c) 2018 Elsevier Ltd

This manuscript version is made available under the CC-BY-NC-ND 3.0 license http://creativecommons.org/licenses/by-nc-nd/3.0/

\section{Data and methods}

\subsection{Case studies of the Duero, Ebro and Tajo river basins}

This study uses daily flow data from thirty-three river gauging stations distributed over the three largest basins in Spain (the Duero, Ebro and Tajo river basins, see Figure 1). The studied locations corresponded to river segments downstream from dams. The requirements for selecting the river gauging stations were 1) there were continuous daily flow data recorded prior to the beginning of dam operation and 2) data were available for the considered period after dam operation. Monitoring stations that met these requirements within the Duero, Ebro and Tajo basins were selected (http://ceh-flumen64.cedex.es/anuarioaforos). All the data referred as "post-dam" come from water releases from the dam, taken directly at the outlet of the reservoir or in the river channel shortly below the dam. Water abstractions usually take place further downstream from the dam in the case of irrigation purposes, whereas they can be located immediately below the dam when water is piped for domestic supply. The studied gauging stations are located in upper and middle river reaches. As in all rivers apart from the evaluated dams there are other dams upstream and downstream, a number of water abstraction points are located in both upstream and downstream the selected gauging stations.

Two time periods were considered in the flow analysis: the pre-dam period (before the construction of the dam) and the post-dam period (after the construction of the dam). The pre-dam period was used to define the hydrological variability in the natural flow regime. The post-impact period, assigned to the period 2000-2010, was utilized to assess the environmental impacts of flow regulation. Table S.1 summarizes the characteristics of the dams and reservoirs, basin areas, mean annual flows, main water use and flow regulation index (i.e., the ratio between the volume of reservoir storing capacity and the volume of natural runoff) of the thirty-three studied river gauging stations. Reservoir volumes ranged from $2 \mathrm{hm}^{3}$ to $2,649 \mathrm{hm}^{3}$, and mean annual river flows were between $0.1 \mathrm{~m}^{3} \mathrm{~s}^{-1}$ and $42.9 \mathrm{~m}^{3} \mathrm{~s}^{-1}$. Main water uses along the river reaches were irrigation, domestic supply and hydroelectricity. Overall, providing water for irrigation was the main purpose of dam construction. However, the goal of hydroelectricity generation was combined with the goal of supplying irrigation water in many cases. 
This document is the Accepted Manuscript version of a Published Work that appeared in final form in:

García de Jalón S., González del Tánago M., García de Jalón D. 2019. A new approach for assessing natural patterns of flow variability and hydrological alterations: The case of the Spanish rivers. JOURNAL OF ENVIRONMENTAL MANAGEMENT. 233. 200-210. DOI (10.1016/j.jenvman.2018.12.049).

(C) 2018 Elsevier Ltd

This manuscript version is made available under the CC-BY-NC-ND 3.0 license http://creativecommons.org/licenses/by-nc-nd/3.0/

Water demands for irrigation in Spain typically take place from May to the end of August, largely covering the summer months, and they normally represent the total amount of water availability of the reservoirs. Overall, irrigation demands represent more than $80 \%$ of the total water storage at national scale in Spain. Water demand for domestic use is much more uniform along the year. It may show some seasonality, being slightly increased in the warmer months to attend demands related to irrigation of urban parks, street cleaning, swimming pools, pollution dilution, etc. but the magnitude of the seasonality is much lower than in agricultural irrigation. The magnitude of demands for domestic supply is very variable across regions but as an average they represent less than $15 \%$ of the water storage in Spain.

Water in Spain, as in many other areas within the Mediterranean region, is a scarce resource with multiple uses and strong demands. The attendance of water demands and criteria driving dam operations are adapted to water availability, which may vary considerably across years. In case of drought periods, prioritization criteria are typically regulated by law, with the following order: $1^{\text {st }}$ ) water supply for domestic consumption, $2^{\text {nd }}$ ) environmental flows, $3^{\text {rd }}$ ) industrial use, and $4^{\text {th }}$ ) irrigation. For irrigation, the prioritization usually takes into account the type of crop, water use efficiency of irrigation and the damage costs of not irrigating.

$<$ INSERTE FIGURE $1>$

\subsection{Analytical methods}

\subsubsection{Assessing the admissible range of flow variability}

The first methodological step of our approach was to define the admissible range of flow variability under natural flow regimes. This range was calculated by using data from the non-regulated period (pre-dam) for each river. The admissible range of flow variability was based on the assumption that flow variability is an intrinsic attribute of the natural flow regime that should be preserved in regulated flows (Poff et al., 1997). Based on the range of daily flows throughout a year within the non-regulated period, an annual hydrograph can be created, and a reference area of natural flow 
This document is the Accepted Manuscript version of a Published Work that appeared in final form in:

García de Jalón S., González del Tánago M., García de Jalón D. 2019. A new approach for assessing natural patterns of flow variability and hydrological alterations: The case of the Spanish rivers. JOURNAL OF ENVIRONMENTAL MANAGEMENT. 233. 200-210. DOI (10.1016/j.jenvman.2018.12.049).

\section{(C) 2018 Elsevier Ltd}

This manuscript version is made available under the CC-BY-NC-ND 3.0 license http://creativecommons.org/licenses/by-nc-nd/3.0/

variability may be devised (see lower graphs in Figure 2 as an example). This reference area of flow variability was used to calculate the environmental impact of flow regulation. Hence, any variation in the daily flows within this range was considered 'admissible', and any variation outside of the admissible range was considered an environmental impact. An exception to this rule is the lowfrequency peak values associated with natural and extraordinary floods or droughts with long return periods, which were identified using precipitation records. Although these flow disturbances can exceed the reference range, we argue that they should not be considered environmental impacts, as they occur under natural conditions, preserve the natural disturbance pattern of the flow regime and have multiple environmental benefits (Bunn and Arthington, 2002).

\subsubsection{Measuring the environmental impact of flow regulation}

The following step of our approach aimed to measure the environmental impact of flow regulation according to the inferred hydrological alteration (changes in magnitude, timing and duration of flows). This was calculated by quantifying differences between current circulating flows and their admissible range of variability (see García de Jalón et al., 2017a for further information).

The environmental impact was calculated for each day during the evaluated post-impact period (2000-2010) as the divergence between the current circulating flows and the reference admissible flow variability. Thus, the estimated environmental impact could be due to either discharges higher than the upper limit of the admissible area (high-flow impacts) or discharges lower than the lower limit (low-flow impacts) (see upper graphs in Figure 2).

Equations 1 and 2 show how high-flow and low-flow impacts ( $H F I_{i, t}$ and $L F l_{i, t}$, respectively) were calculated for a given river reach $i$ at time instant $t$. Both impacts were calculated as the distance from the high and low limits of the admissible area of discharge. To normalize the estimated $\mathrm{HFI}$ and $L F I$, the difference between the current flow $(C F)$ value and the reference flow value was divided by the maximum flow value.

$$
\begin{aligned}
& H F I_{i, t}=\frac{C F_{i, t}-H R F_{i, t}}{C F_{i, t}} \\
& L F I_{i, t}=\frac{L R F_{i, t}-C F_{i, t}}{L R F_{i, t}}
\end{aligned}
$$


This document is the Accepted Manuscript version of a Published Work that appeared in final form in:

García de Jalón S., González del Tánago M., García de Jalón D. 2019. A new approach for assessing natural patterns of flow variability and hydrological alterations: The case of the Spanish rivers. JOURNAL OF ENVIRONMENTAL MANAGEMENT. 233. 200-210. DOI (10.1016/j.jenvman.2018.12.049).

\section{(c) 2018 Elsevier Ltd}

This manuscript version is made available under the CC-BY-NC-ND 3.0 license http://creativecommons.org/licenses/by-nc-nd/3.0/

where HRF is the upper limit of the reference area of admissible flows and LRF is the lower limit of the reference area.

The environmental impact assessment considered changes in not only the magnitude and timing of flows but also the flow duration. Moving averages of daily discharges for three, seven and thirty consecutive days were calculated, and high-flow and low-flow impacts were calculated as the average of the estimated impacts for one, three, seven and thirty days, respectively. The environmental impact of flow regulation was calculated as the sum of these average values of highflow and low-flow impacts.

$<$ INSERTE FIGURE $2>$

Both calculations - the admissible range of flow variability based on pre-dam data and the environmental impact of flow regulation based on post-dam data - were calculated in the thirtythree river locations using the R package 'FlowRegEnvCost' (García de Jalón et al., 2017b) in R software (R Core Team, 2013).

\subsubsection{Assessing types of flow variability, environmental impact and seasonal distribution}

The next methodological step of our approach aimed to sort the thirty-three rivers into groups, or 'clusters', that were internally homogeneous (i.e., the natural flow variability or environmental impacts in each cluster were closely related) but distinct from the other groups. In doing so, the estimated admissible range of flows in natural regimes (pre-dam period) and flow impacts during 2000-2010 (post-dam period) were separately classified using a hierarchical cluster analysis technique (MacQueen, 1967; Anderberg, 1973). The R software package 'stats' (R Core Team and contributors worldwide, 2013) was used for the computation of clusters and the visualization of results.

Hierarchical clustering algorithms typically use a defined 'distance', which is a measure of the similarity of two elements $(x, y)$ between objects, in a dataset to quantify the strength of relationships (Lindsey et al., 2018). In this study, the Euclidean distance was used to compute the 
This document is the Accepted Manuscript version of a Published Work that appeared in final form in:

García de Jalón S., González del Tánago M., García de Jalón D. 2019. A new approach for assessing natural patterns of flow variability and hydrological alterations: The case of the Spanish rivers. JOURNAL OF ENVIRONMENTAL MANAGEMENT. 233. 200-210. DOI (10.1016/j.jenvman.2018.12.049).

\section{(c) 2018 Elsevier Ltd}

This manuscript version is made available under the CC-BY-NC-ND 3.0 license http://creativecommons.org/licenses/by-nc-nd/3.0/

dissimilarity matrix (Equation 3). The Euclidean distance is the ordinary straight-line distance in parameter space between two points (Rencher and Christensen, 2012).

$$
d_{e u c}(x, y)=\sqrt{\sum_{i=1}^{p}\left(x_{i}-y_{i}\right)^{2}}
$$

where $x$ and $y$ are two vectors of length $p$.

Hierarchical cluster analysis uses the distance between objects to create a tree-based representation of the relationships between objects, known as a dendrogram. By cutting the dendrogram at a desired similarity level, observations can be subdivided into groups. In this study, the objects were the river segments at the gauging stations, and the attributes were the values of the admissible area of river flows and the estimated flow regulation impacts on a daily basis. Each object occupies a mutually exclusive position in the dendrogram (Everitt and Holthorn, 2010). The separation or distance between the branches of the dendrogram indicates the closeness or remoteness of a relationship. To compute the hierarchical clustering and to define the groups, a Ward's minimum variance method was used. The criterion in Ward's method was to minimize the total within-cluster variance and was calculated using a Lance-Williams algorithm within the family of agglomerative hierarchical clustering algorithms.

Subsequently, the identified groups of patterns in flow variability and flow regulation impacts were compared and characterized according to differences in hydrologic regime (i.e., magnitude, duration and seasonality of the impacts) and main water use. A MANOVA test was used to determine whether admissible ranges of flow variability and low-flow and high-flow impacts differed among the river basins and among the identified clusters. Then, an ANOVA test was used to determine whether significant differences existed among flow variability, low-flow impacts, high-flow impacts and total flow impacts. We followed the ANOVA with Tukey's honestly significant difference (HSD) test to determine whether each pairwise comparison had a significant difference. 
This document is the Accepted Manuscript version of a Published Work that appeared in final form in:

García de Jalón S., González del Tánago M., García de Jalón D. 2019. A new approach for assessing natural patterns of flow variability and hydrological alterations: The case of the Spanish rivers. JOURNAL OF ENVIRONMENTAL MANAGEMENT. 233. 200-210. DOI (10.1016/j.jenvman.2018.12.049).

(c) 2018 Elsevier Ltd

This manuscript version is made available under the CC-BY-NC-ND 3.0 license http://creativecommons.org/licenses/by-nc-nd/3.0/

\section{Results}

\subsection{Admissible range of flow variability in the Duero, Ebro and Tajo river}

\section{basins}

Firstly, the admissible range of flow variability was calculated on the basis of the variability in the daily river flows during the pre-dam period. The resulting estimated admissible range of variability in the thirty-three studied flow-gauging stations can be found in the supplementary material of this manuscript (see Figures S.1, S.2 and S.3 for the monitoring stations in the Duero, Ebro and Tajo river basins, respectively). Although the estimated admissible range of river flows varied among the river segments, it was generally relatively broad from late October to early June and very narrow from July to September. This pattern is characteristic of Mediterranean basins, where precipitation can be highly variable between late autumn and late spring and is very low during the summer months (de Luis et al., 2010; Deitch et al., 2017).

From the hierarchal cluster analysis results, a 'dendrogram' (Figure 3) and a 'scree plot' (Figure S.4) were calculated. The dendrogram illustrates the arrangement of the clusters produced by hierarchical clustering, and the scree plot shows the sum-of-squares as a function of the number of clusters. From these plots, 3 clusters that represent three distinct hydrologic regime patterns were selected.

The first identified cluster (i.e., Type I in Figure 3) includes rivers exclusively from the Ebro basin and is representative of a fluctuating nivo-pluvial regime, with snowmelt peak flows in late spring, two secondary high-flow periods during rainfall seasons in autumn and late winter, and a short window of summer drought (Figure 4). The second cluster (Type II) is largely dominated by rivers from the Duero basin, with three additional river locations from the Ebro basin and one from the Tajo basin. This group contains rivers with much higher runoff than the first cluster and can be characterized as a seasonal, pluvio-nival (autumn-winter) regime, having an extended period of relatively constant high flows from early November to May and a short period of low flows during the summer months. Finally, the third cluster (Type III) includes most of the rivers from the Tajo basin (eight of nine rivers), although it also includes five rivers located in the middle or lower reaches of the Duero basin and two small rivers in the Ebro basin. As a whole, this group of rivers roughly covers most of the 
This document is the Accepted Manuscript version of a Published Work that appeared in final form in:

García de Jalón S., González del Tánago M., García de Jalón D. 2019. A new approach for assessing natural patterns of flow variability and hydrological alterations: The case of the Spanish rivers. JOURNAL OF ENVIRONMENTAL MANAGEMENT. 233. 200-210. DOI (10.1016/j.jenvman.2018.12.049).

(C) 2018 Elsevier Ltd

This manuscript version is made available under the CC-BY-NC-ND 3.0 license http://creativecommons.org/licenses/by-nc-nd/3.0/

southern and dry sub-basins in the studied area and reflects a strongly seasonal, pluvial (winter) hydrologic regime. Most high-flow pulses are concentrated in a short window between February and early March, and low flows extend across the warmer months between early June and early October (Figure 4).

$<$ INSERTE FIGURE $3>$

$<$ INSERTE FIGURE $4>$

\subsection{Flow regulation impact}

Figure 5 shows the distribution of low-flow and high-flow impacts in the studied river locations, grouped by river basins. The boxplots show the range of values of daily low-flow and high-flow impacts between 2000 and 2010. The bottom and top whiskers indicate minimum and maximum impact values, respectively. The bottom and top lines of the boxes indicate the values of the $25^{\text {th }}$ percentile and the $75^{\text {th }}$ percentile, respectively, and the line within each box represents the median values.

Low-flow impacts are presented in the three graphs on the left side of Figure 5 . For $87.9 \%$ of the thirty-three gauging stations, there was no low-flow impact for more than $50 \%$ of the studied days in 2000-2010 (median value equal to zero). In the Barrios de Luna, Linares del Arroyo, Reinosa and Tejera reservoirs, low-flow impacts occurred on more than $50 \%$ of the days. The 75 th percentile was equal to zero for $42.4 \%$ of the monitoring stations, which indicated that there was no low-flow impact for more than $75 \%$ of the studied days. Overall, rivers in the Tajo basin had the greatest lowflow impact, followed by the Duero and Ebro basins (see Table S.2 in the supplementary material for more detailed information).

High-flow impacts are shown on the right side of Figure 5. For all monitoring stations, there was no high-flow impact for more than 50\% of the days in 2000-2010 (median value equal to zero) as highflow impacts are typically more concentrated in the early summer when water needs for irrigation are higher. More than $75 \%$ of the studied days had no high-flow impacts at $51.5 \%$ of the monitoring stations. In the Duero basin, only the Pontón Alto station had $75 \%$ of the studied days with no high- 
This document is the Accepted Manuscript version of a Published Work that appeared in final form in:

García de Jalón S., González del Tánago M., García de Jalón D. 2019. A new approach for assessing natural patterns of flow variability and hydrological alterations: The case of the Spanish rivers. JOURNAL OF ENVIRONMENTAL MANAGEMENT. 233. 200-210. DOI (10.1016/j.jenvman.2018.12.049).

(c) 2018 Elsevier Ltd

This manuscript version is made available under the CC-BY-NC-ND 3.0 license http://creativecommons.org/licenses/by-nc-nd/3.0/

flow impact. Rivers in the Duero basin had the greatest high-flow impact followed by rivers in the Tajo and Ebro basins (Table S.2).

A MANOVA, with low-flow and high-flow impacts comprising a single multivariate response variable, revealed a statistically significant difference $(P<0.001)$ among the three river basins (Table S.2). ANOVA tests revealed that low-flow, high-flow and total flow impacts differed significantly among the three basins $(P<0.001)$. Tukey's HSD tests showed that the three basins were significantly different from each other $\left(P_{a d}<0.001\right)$.

$<$ INSERTE FIGURE $5>$

Further correlation analyses between hydrological impacts and the potential explanatory variables shown in Table S.1 (i.e., elevation, volume capacity, drainage area, and impounding ratio) were conducted and revealed very weak (statistically insignificant) relationships across the studied sites.

\subsection{Types of flow regulation impacts and seasonal distribution}

Figure 6 shows the dendrogram developed to illustrate the arrangement of the clusters according to the estimated daily flow regulation impacts in the post-dam period (2000-2010). The first identified cluster was named 'constant low-intensity' and included three gauging stations from the Duero basin (42.9\%), one from the Ebro basin (14.3\%) and three from the Tajo basin (42.9\%). The second cluster was named 'seasonal' and included two monitoring stations from the Duero basin (11.8\%), ten from the Ebro basin (58.8\%) and five from the Tajo basin (29.4\%). The last cluster was named 'constant high-intensity' and included seven stations from the Duero basin (77.8\%), one from the Ebro basin (11.1\%) and one from the Tajo basin (11.1\%).

$<$ INSERTE FIGURE $6>$ 
This document is the Accepted Manuscript version of a Published Work that appeared in final form in:

García de Jalón S., González del Tánago M., García de Jalón D. 2019. A new approach for assessing natural patterns of flow variability and hydrological alterations: The case of the Spanish rivers. JOURNAL OF ENVIRONMENTAL MANAGEMENT. 233. 200-210. DOI (10.1016/j.jenvman.2018.12.049).

\section{(C) 2018 Elsevier Ltd}

This manuscript version is made available under the CC-BY-NC-ND 3.0 license http://creativecommons.org/licenses/by-nc-nd/3.0/

Once the three types of flow regulation were identified, the seasonality of the impacts were compared. Figure 7 shows daily mean values of low-flow (red and downwards bars) and high-flow (blue and upwards bars) impacts of all gauging stations within each cluster in the post-dam period. The cluster 'constant low-intensity' includes rivers in which both low-flow and high-flow impacts are typically not very large in magnitude, or if they are large, then the duration and/or the frequency of the impact is relatively short. Although they can be produced at any time of the year, high-flow impacts are often produced from July to early September, and low-flow impacts occur during the rest of the year. Rivers with 'seasonal' impacts are those in which there is a clear difference between the months with high-flow impacts and the months with low-flow impacts. During the summer months, high-flow impacts are rather strong, and low-flow impacts are produced very rarely. The period of high-flow impacts is notably longer in rivers with 'constant low-intensity' impacts and usually lasts from late June to late October. Rivers with 'constant high-intensity' impacts are a combination of 'constant low-intensity' and 'seasonal' rivers. Low-flow impacts can be produced at any time of the year; nevertheless, they are typically generated between late September and June. High-flow and low-flow impacts are relatively strong from November to April and from July to August, respectively.

$<$ INSERTE FIGURE 7 >

Table 1 shows the means, standard deviations and various statistical tests used to assess differences among the identified types of flow regulation impacts (rivers with constant low-intensity impact, rivers with seasonal impact and rivers with constant high-intensity impact). The MANOVA test, with low-flow and high-flow impacts comprising a single multivariate response variable, revealed statistically significant differences $(P<0.001)$ among the identified types of flow regulation impacts. Subsequently, the ANOVA tests showed that low-flow, high-flow and total flow impacts differed significantly among the three clusters when assessed separately by impact $(P<0.001)$. Tukey's HSD tests showed that the three types of flow regulation impacts were significantly different from each other (all cases have a $P_{a d j}<0.001$ except seasonal-constant low-intensity with $P_{a d j}=0.002$ ).

$<$ INSERTE TABLE $1>$ 
This document is the Accepted Manuscript version of a Published Work that appeared in final form in:

García de Jalón S., González del Tánago M., García de Jalón D. 2019. A new approach for assessing natural patterns of flow variability and hydrological alterations: The case of the Spanish rivers. JOURNAL OF ENVIRONMENTAL MANAGEMENT. 233. 200-210. DOI (10.1016/j.jenvman.2018.12.049).

(c) 2018 Elsevier Ltd

This manuscript version is made available under the CC-BY-NC-ND 3.0 license http://creativecommons.org/licenses/by-nc-nd/3.0/

\section{Discussion}

\subsection{Natural patterns of admissible range of flow variability}

The methodological approach used in this research allowed the identification of different patterns of natural flow variability across the studied rivers (Figures 3,4 ). The results roughly represent an integrated response to distinct geographical contexts. In the studied rivers, the durations and seasonal distributions of high flows and low flows throughout the year resulted in three different types of hydrologic regimes (Figure 4). The resulting hydrologic types are probably associated with spatially distinct areas. In the dendrogram (see Figure 3), the first differentiated aggregation (cluster Type I) corresponds to rivers emerging from the Pyrenees and that belong to the Ebro basin. These rivers exhibit typical nivo-pluvial regimes with primarily high flows derived from snowmelt alternating with periods of low flow corresponding to periods of snowfall and dry summer months during the year. The second cluster (Type II) mostly contains north-western rivers belonging to the Duero basin. These rivers collect larger amounts of runoff from the Cantabrian Mountains than rivers in the Tajo basin and have a mixed hydrologic regime with a long period of high flows from rainfall and snowmelt and a relatively short period of low flows. The third cluster in the dendrogram (Type III) roughly corresponds to rivers in Central Spain, mainly located in the Tajo basin, where most of the natural runoff comes from rainfall. These rivers display a typical pluvial regime with a short period of high flows and a relatively long period of low to medium flows. The characterization of these flow regime types is illustrated by their natural patterns of flow variability throughout the year. Overall, this characterization represents a suitable framework for classifying flow regime types and assessing flow regulation impacts derived from the augmentation or the depletion of flows outside the admissible boundaries. The resulting flow regime classification, primarily based on magnitude, duration and seasonal distribution of high and low flows, offers hydrologic support for developing scientifically based environmental flow guidelines at a regional scale (Arthington et al., 2006; Poff et al., 2010). Our findings may help in regionalizing the natural patterns of flow variability in rivers of Central and Northern Spain and could serve as a reference for the acceptable range of temporal fluctuation patterns of regulated flows to mimic geographical variability and prevent the homogenization of flows. 
This document is the Accepted Manuscript version of a Published Work that appeared in final form in:

García de Jalón S., González del Tánago M., García de Jalón D. 2019. A new approach for assessing natural patterns of flow variability and hydrological alterations: The case of the Spanish rivers. JOURNAL OF ENVIRONMENTAL MANAGEMENT. 233. 200-210. DOI (10.1016/j.jenvman.2018.12.049).

\section{(C) 2018 Elsevier Ltd}

This manuscript version is made available under the CC-BY-NC-ND 3.0 license http://creativecommons.org/licenses/by-nc-nd/3.0/

For the Duero basin, Morán-Tejeda et al. (2011) analysed precipitation and flow regime conditions throughout the basin and provided a flow regime classification according to rain-based versus snowbased runoff and timing of annual peak flows. This classification was similar to that obtained in our research but without its potential use in the quantification of hydrological impacts. For the Ebro basin, Solans and Poff (2012) classified the natural flow regimes using a wide range of hydrologic parameters based on monthly flows. Up to 54 hydrologic variables representing magnitude, frequency and duration components of flow were used in their research to classify six different types of flow regime, mainly based on differences in climate and watershed characteristics (i.e., ranging from pluvio-oceanic in the western part of the Ebro basin to Mediterranean in the eastern part). The procedure followed by these authors used previous statistical analyses to address scale effects, correlation between variables and stepwise and canonical discriminant analysis in order to identify significantly distinct flow regime types. In our case, a spare-parameter approach provided similar findings for a natural flow regime classification at the regional scale, with relevant advantages of delineating boundaries (i.e., admissible range of flow variability) in which the thresholds of magnitude and seasonal distribution of daily flows may be established to inform environmental flows procedures.

Arthington et al. (2006) and Poff et al. (2010) encouraged the identification of the natural trends in flow variability for the design of environmental flow rules that mimic components of pre-dam hydrologic regimes. For this purpose, many other authors have also advocated for the classification of natural flow regimes to inform regional water resources planning (Baeza and García de Jalón, 2005; Snelder et al., 2009; Bejarano et al., 2010; Olden et al., 2012; Peñas et al., 2016). Our methodological approach has demonstrated to be very useful for visualizing the continuum of the natural flow variability during the year and for identifying classes of streams in which the magnitude and seasonal distribution of daily flows may be established and flow regulation patterns and hydrological impacts can be properly calibrated.

\subsection{General trends in flow regulation impacts in a Mediterranean context}

In the evaluated rivers, three significantly different types of patterns of flow regulation impacts were identified with distinct intensities but similar seasonal distributions of impacts (Figures 6 and 7). The irrigation demand for water is the main use in most of the studied river reaches and its seasonality strongly influences the Low- and High-flow impacts. Low-flow impacts were the most frequent and occurred between October and June. This period corresponds to the months when reservoirs are 
This document is the Accepted Manuscript version of a Published Work that appeared in final form in:

García de Jalón S., González del Tánago M., García de Jalón D. 2019. A new approach for assessing natural patterns of flow variability and hydrological alterations: The case of the Spanish rivers. JOURNAL OF ENVIRONMENTAL MANAGEMENT. 233. 200-210. DOI (10.1016/j.jenvman.2018.12.049).

\section{(C) 2018 Elsevier Ltd}

This manuscript version is made available under the CC-BY-NC-ND 3.0 license http://creativecommons.org/licenses/by-nc-nd/3.0/

being filled from direct runoff driven by precipitation, and water demands are reduced. High-flow impacts took place during a much shorter period between July and September and corresponded to large water releases from the reservoirs, primarily for agricultural irrigation. These results showed that flow regulation impacts do not reflect differences in natural flow variability previously identified across regional areas but directly depend on patterns of water demand. First, the assessment of the admissible range of flow variability identified some differences across regional areas (see Section 3.1). Second, the river reaches within the clusters identified according to natural flow variability (pre-dam period, Figure 3) considerably differ with the clusters identified according to flow regulation impacts (post-dam period, Figure 6). Third, flow regulation impacts of river reaches notably vary within each basin which indicates that the region is not an important determinant of the impact. This is reflected in Table S.2 which shows that the standard deviation of the impacts of the river reaches in each basin is considerably greater than the mean. Nevertheless, additional information on water uses and water demands from each reservoir, which remain out of the scope of our research, could provide a better basis and evidences for our arguments.

McManamay et al. (2012) evaluated patterns of hydrologic alteration due to dams in rivers of the south-eastern United States and found that the magnitude and direction of dam effects on stream flows were strongly influenced by previously identified flow regime classes. Besides, the widely accepted ELOHA approach (Poff et al., 2010) suggested ecologically based limits of hydrologic alteration based on previous regionalization of natural flow regimes. It can be hypothesized that patterns of admissible hydrological alteration should be linked to patterns of natural variability in flows to guarantee that regulated rivers preserve their intrinsic hydrologic signatures. The results shown in Figure 5 indicate that classes of hydrologic impacts are not influenced by local climate and geomorphological conditions; instead, they strongly depend on dam operation and water demands. Our results suggest that in Mediterranean regions, most dammed rivers show similar patterns of hydrologic alteration, with depletion of flows during winter and spring and enhancement of flows during summer months, with little regard to their respective natural flow regime typologies (Kondolf and Batalla, 2005; Morán-Tejeda et al., 2011; Lorenzo-Lacruz et al., 2012). Such a water resources management approach overrides the different natural conditions of rivers and homogenizes their flow patterns.

The rivers in the Ebro basin seem to be the least impaired by damming, the rivers in the Duero basin are the most altered by high flows, and the rivers in the Tajo basin are the most altered by low flows (Figure 5). Overall, it seems that rivers in the Duero basin suffer the strongest seasonal flow 
This document is the Accepted Manuscript version of a Published Work that appeared in final form in:

García de Jalón S., González del Tánago M., García de Jalón D. 2019. A new approach for assessing natural patterns of flow variability and hydrological alterations: The case of the Spanish rivers. JOURNAL OF ENVIRONMENTAL MANAGEMENT. 233. 200-210. DOI (10.1016/j.jenvman.2018.12.049).

\section{(C) 2018 Elsevier Ltd}

This manuscript version is made available under the CC-BY-NC-ND 3.0 license http://creativecommons.org/licenses/by-nc-nd/3.0/

regulation impacts. This result could be explained by the fact that without any environmental costs and/or social constraints, as in the case of Spanish water policy, environmental impacts of flow regulation may be higher for the Duero basin rivers because of their higher natural runoff (i.e., they are able to store more water in large reservoirs, e.g., the Riaño, Barrios de Luna, and Vegamián dams, than other rivers, allowing them to release higher flows in summer). These higher flow regulation impacts do not seem to be due to higher agricultural production or urban demands. In contrast, the rivers in the Tajo basin have flow regulation impacts associated with limited runoff availability and high urban and industrial demands. Thus, introducing the environmental costs of water use into water resources management and policy, as the WFD requires to achieve the fullcost recovery of water use, is an unavoidable task in the reduction of hydrological impacts and the promotion of better trade-offs between environmental impairment and water regulation benefits.

\subsection{Potential of the methodological approach}

The approach used in this study differs from other methodologies widely used for assessing flow regulation impacts. Traditionally, the hydrologic shifts associated with river damming have been frequently assessed using 32 indicators of hydrological alteration that were initially proposed by Richter et al. (1996), further reviewed by Olden and Poff (2003), and completed by other authors (e.g., McManamay et al., 2012). These 32 indicators were developed because of their close association with ecological functioning, and the indicators refer to the magnitude of monthly flows, magnitude and duration of extreme conditions, timing of annual extreme conditions, frequency and duration of high and low pulses and rate and frequency of changes in conditions. The application of Richter's indices to pre-dam and post-dam flow conditions provides a complete description of hydrologic changes that are due to flow regulation. This information is referred to as discrete flow regime attributes (e.g., average monthly discharge, 1-day annual maximum, rise rate, and reversals), which are typically calculated as average values over a period of years. Although together these indicators largely characterize the regulated flow regime, this methodology does not combine the intensities of hydrologic alterations into single parameters able to be translated into economic terms, nor can the results be graphically visualized on a daily basis in an annual hydrograph. This graphical limitation inhibits the design of better daily flow regulation options and hinders communication with stakeholders.

The approach followed in this research overcomes the aforementioned limitations. It enables the quantitative and graphical definition of the admissible range of flow variability during a year and 
This document is the Accepted Manuscript version of a Published Work that appeared in final form in:

García de Jalón S., González del Tánago M., García de Jalón D. 2019. A new approach for assessing natural patterns of flow variability and hydrological alterations: The case of the Spanish rivers. JOURNAL OF ENVIRONMENTAL MANAGEMENT. 233. 200-210. DOI (10.1016/j.jenvman.2018.12.049).

\section{(c) 2018 Elsevier Ltd}

This manuscript version is made available under the CC-BY-NC-ND 3.0 license http://creativecommons.org/licenses/by-nc-nd/3.0/

encompasses the natural diversity of flow conditions (i.e., the range between the $10^{\text {th }}$ and $90^{\text {th }}$ percentiles, which was also proposed by other authors to encompass historical range and variability [e.g., Keane et al., 2009]). Additionally, the visualization of this range of admissible variability in the annual hydrograph helps the discussion with stakeholders of potential proposals of regulated daily flow seasonality that preserve critical functional flows in terms of magnitude, duration and timing while coping with water demands. By using admissible boundaries of flow variability that have been previously estimated and graphically represented, agreements on the total amount of water to be impounded, in both in-channel and off-channel structures, and ways for water to be released by dams in a more environmentally based seasonal distribution during a year may be more easily achieved.

The methodology encompasses the natural flow hydrograph and represents a practical tool for exploring flow regulation options that minimize deviations from the admissible range of flow variability. However, the rationale of the methodology strongly depends on the selection of a predam period that will be considered a "reference". Difficulties in obtaining reference data in the predam period arise from not only the availability of flow-gauging stations with sufficient data but also potential changes in climate and land cover and uses at the catchment scale, which could induce hydrologic shifts over time (Morán-Tejeda et al., 2011; García-Ruiz et al., 2011) and increase the complexity of assigning reference flow conditions for comparison.

These limitations could be overcome by using hydrological models to generate historical flow series from current climate and watershed conditions, from which the admissible range of flow variability could be derived. Furthermore, the hydrological modelling approach could also be used to generate predicted future flow series under different scenarios of climate change.

As occurs with other flow analysis approaches, having consistent recorded historical flow data is essential for finding representative results. Deficiencies in the number of gauging stations and the length of data records could reduce the validity of the conclusions, which highlights the importance of extending river gauging stations in Spanish rivers to properly understand current river hydrological functioning. The scarcity of gauging stations with complete and continuous data for long time periods hinders assessing how far the impacts (i.e., High- and Low-impacts) occur along the river reaches downstream. Nevertheless, taking into account the frequent inadequacy of available data, we argue that our methodological approach is very efficient in providing basic 
This document is the Accepted Manuscript version of a Published Work that appeared in final form in:

García de Jalón S., González del Tánago M., García de Jalón D. 2019. A new approach for assessing natural patterns of flow variability and hydrological alterations: The case of the Spanish rivers. JOURNAL OF ENVIRONMENTAL MANAGEMENT. 233. 200-210. DOI (10.1016/j.jenvman.2018.12.049).

\section{(C) 2018 Elsevier Ltd}

This manuscript version is made available under the CC-BY-NC-ND 3.0 license http://creativecommons.org/licenses/by-nc-nd/3.0/

information about flow regimes and hydrological impacts and, at the same time, is appropriate for transparent communication with stakeholders.

Finally, this methodological approach offers new perspectives for the design of environmental flows and for economic assessments of flow regulation impacts in a simple and practical way. In terms of environmental flows, our approach is similar to the "sustainability boundary approach" of Richter (2010), in which limiting water withdrawals to a fixed proportion of natural flows is proposed. In our case, we explicitly identify the range of natural variability in an annual hydrograph and quantify the environmental impacts when flow regulation deviates from its natural range. In terms of economic issues, which are necessary to improve water-use efficiency and need to be included in water policies according to the WFD and the Environmental Liability Directive (EC, 2004), our methodology enables the calculation of environmental costs proportionally to environmental impacts. In communication processes with stakeholders, distinct, potential regulation options may emerge that address the same amount of stored water but with different seasonal release times, with the aim of fitting within previously defined admissible range of flow variability. This could be implemented by storing water in off-channel reservoirs which would be filled during the rainy season to minimize hydrological impacts. This solution has started to be implemented in certain areas of the Segura River (South east of Spain), that are strongly dependent on water transfers from other basins in which water availability is not fully guaranteed every year.

\section{Conclusions}

This study presents a methodology to characterize the natural patterns of flow variability and to define the admissible range outside of which the hydrological impacts of flow regulation can be quantified, in terms of high-flow impacts above the admissible range and low-flow impacts below the admissible range. The methodology has been applied to 33 river sites below dams. Differences in flow magnitude, duration and timing have been used to classify natural river flow variability types, which roughly correspond to distinct geographical areas under different climatologic contexts. However, the seasonality of hydrological impacts has been found to be very similar for all river groups, responding to the primary water demands in Mediterranean regions typically associated with irrigation. High-flow impacts are often produced from July to early September, and low-flow impacts are produced during the rest of the year. This temporal distribution of hydrological impacts, with little influence from their respective natural flow regime typologies, could be considered typical 
This document is the Accepted Manuscript version of a Published Work that appeared in final form in:

García de Jalón S., González del Tánago M., García de Jalón D. 2019. A new approach for assessing natural patterns of flow variability and hydrological alterations: The case of the Spanish rivers. JOURNAL OF ENVIRONMENTAL MANAGEMENT. 233. 200-210. DOI (10.1016/j.jenvman.2018.12.049).

(c) 2018 Elsevier Ltd

This manuscript version is made available under the CC-BY-NC-ND 3.0 license http://creativecommons.org/licenses/by-nc-nd/3.0/

in most dammed rivers in the Mediterranean region. The depletion of flows during winter and spring and the rising of flows during summer months imply the loss of natural Mediterranean flow variability, promoting the homogenization of river hydro-morphological conditions.

Our approach substantially differs from other hydrological alteration assessment procedures. It considers deviations from the admissible range of natural flow variability on a daily basis and allows the quantification of impacts under different water release scenarios in an easy and flexible way. This study has demonstrated that this approach is very useful for regionalizing the natural flow regimes as a first step to guide environmental flow standards. The approach also allows the identification of differences in the magnitude of hydrological impacts, which can be translated to environmental costs in monetary terms. Thus, this methodology offers a new spare-parameter approach for assessing the hydrological impacts of flow regulation that corresponds well to the requirements of the Water Framework Directive and should be tested in other regions. Overall, this methodology facilitates communication and agreements with stakeholders and represents a practical management tool for decreasing the environmental impacts of flow regulation and increasing efficiency in water use.

\section{References}

Anderberg, M.R., 1973. Cluster Analysis for Applications. Probability and Mathematical Statistics. Academic Press, Inc. NY.

Aparicio, E., Vargas, M.J., Olmo, J.M., De Sostoa, A., 2000. Decline of native freshwater fishes in a Mediterranean watershed on the Iberian Peninsula: a quantitative assessment. Environ. Biol. Fish. 59(1), 11-19.

Arthington, A.H., Bunn, S.E., Poff, N.L., Naiman, R.J., 2006. The challenge of providing environmental flow rules to sustain river ecosystems. Ecol. Appl. 16(4), 1311-1318.

Baeza Sanz, D., García de Jalón, D., 2005. Characterization of streamflow regimes in central Spain, based on relevant hydrobiological parameters. J. Hydrol. 310 (1-4), 266-279.

Batalla, R.J., Gomez, C.M., Kondolf, G. M., 2004. Reservoir-induced hydrological changes in the Ebro River basin (NE Spain). J. Hydrol. 290(1-2), 117-136. 
This document is the Accepted Manuscript version of a Published Work that appeared in final form in:

García de Jalón S., González del Tánago M., García de Jalón D. 2019. A new approach for assessing natural patterns of flow variability and hydrological alterations: The case of the Spanish rivers. JOURNAL OF ENVIRONMENTAL MANAGEMENT. 233. 200-210. DOI (10.1016/j.jenvman.2018.12.049).

(c) 2018 Elsevier Ltd

This manuscript version is made available under the CC-BY-NC-ND 3.0 license http://creativecommons.org/licenses/by-nc-nd/3.0/

Bejarano, M.D., Marchamalo, M., García de Jalón, D., González del Tánago, M., 2010. Flow regime patterns and their controlling factors in the Ebro basin (Spain). J. Hydrol. 385 (1-4), 323-335.

Bithas, K., 2008. The sustainable residential water use: Sustainability, efficiency and social equity. The European experience. Ecol. Econ. 68 (1), 221-229

Bunn, S.E., Arthington, A.H., 2002. Basic principles and ecological consequences of altered flow regimes for aquatic biodiversity. Environ. Manage. 30 (4), 492-507.

Cid, N., Bonada, N., Carlson, S.M., Grantham, T.E., Gasith, A., Resh, V.H., 2017. High variability is a defining component of Mediterranean-climate rivers and their biota. Water 9(1), 52.

Cooper, B., Crase, L., Pawsey, N., 2014. Best practice pricing principles and the politics of water pricing. Agr. Water Manage. 145, 92-97.

de Luis, M., Brunetti, M., Gonzalez-Hidalgo, J.C., Longares, L.A., Martin-Vide, J., 2010. Changes in seasonal precipitation in the Iberian Peninsula during 1946-2005. Global Planet. Change 74(1), 27-33.

Deitch, M.J., Sapundjieff, M.J., Feirer, S.T., 2017. Characterizing precipitation variability and trends in the world's Mediterranean-Climate areas. Water 9(4), 259.

Döll, P., Fiedler, K., Zhang, J., 2009. Global-scale analysis of river flow alterations due to water withdrawals and reservoirs. Hydrol. Earth Syst. Sc. 13(12), 2413.

EC (European Commission), 2000. Directive 2000/60/CE of 23 October 2000 establishing a framework for Community action in the field of water policy. Official Journal of the European communities, 22 December 2000.

EC (European Commission), 2004. Directive 2004/35/CE of 21 April 2004 on environmental liability with regard to the prevention and remedying of environmental damage. Official Journal of the European Union, 30 April 2004.

Everitt, B., Holthorn, T., 2010. A Handbook of Statistical Analyses Using R. CRC Press, Boca Raton, FL. 
This document is the Accepted Manuscript version of a Published Work that appeared in final form in:

García de Jalón S., González del Tánago M., García de Jalón D. 2019. A new approach for assessing natural patterns of flow variability and hydrological alterations: The case of the Spanish rivers. JOURNAL OF ENVIRONMENTAL MANAGEMENT. 233. 200-210. DOI (10.1016/j.jenvman.2018.12.049).

(c) 2018 Elsevier Ltd

This manuscript version is made available under the CC-BY-NC-ND 3.0 license http://creativecommons.org/licenses/by-nc-nd/3.0/

García de Jalón, S., González del Tánago, M., Alonso, C., García de Jalón, D., 2017a. The environmental costs of water flow regulation: an innovative approach based on the 'polluter pays' principle. Water Resour. Manag. 31 (9), 2809-2822.

García de Jalón, S., Martínez-López, J., González del Tánago, M., Alonso, C., García de Jalón, D., 2017b. FlowRegEnvCost: The Environmental Costs of Flow Regulation. R package version 0.1.1. Available at: https://cran.r-project.org/web/packages/FlowRegEnvCost/index.html, and https://github.com/garciadejalon/FlowRegEnvCost.

García-Ruiz, J.M., López-Moreno, J.I., Vicente-Serrano, S.M., Lasanta-Martínez, T., Beguería, S., 2011. Mediterranean water resources in a global change scenario. Earth Sc. Reviews 105(34), 121-139.

González del Tánago, M., Bejarano, M.D., García de Jalón, D., Schmidt, J.C., 2015. Biogeomorphic responses to flow regulation and fine sediment supply in Mediterranean streams (the Guadalete River, southern Spain). J. Hydrol. 528, 751-762.

Grantham, T.E., Figueroa, R., Prat, N., 2013. Water management in Mediterranean river basins: a comparison of management frameworks, physical impacts, and ecological responses. Hydrobiologia 719(1), 451-482.

Grindlay, A.L., Zamorano, M., Rodríguez, M.I., Molero, E., Urrea, M.A., 2011. Implementation of the European Water Framework Directive: Integration of hydrological and regional planning at the Segura River Basin, southeast Spain. Land Use Policy 28(1), 242-256.

Hall, A.A., Rood, S.B., Higgins, P.S., 2009. Resizing a river: A downscaled, seasonal flow regime promotes riparian restoration. Restor. Ecol. 19(3), 351-359.

Hooke, J.M., 2006. Human impacts on fluvial systems in the Mediterranean region. Geomorphology 79(3-4), 311-335.

Keane, R.E., Hessburg, P.F., Landres, P.B., Swanson, F.J., 2009. The use of historical range and variability (HRV) in landscape management. Forest Ecol. Manag. 258(7), 1025-1037.

Kondolf, G.M., Batalla, R.J., 2005. Hydrological effects of dams and water diversions on rivers of Mediterranean-climate regions: examples from California. Dev. Earth Surface Process. 7, 197211. 
This document is the Accepted Manuscript version of a Published Work that appeared in final form in:

García de Jalón S., González del Tánago M., García de Jalón D. 2019. A new approach for assessing natural patterns of flow variability and hydrological alterations: The case of the Spanish rivers. JOURNAL OF ENVIRONMENTAL MANAGEMENT. 233. 200-210. DOI (10.1016/j.jenvman.2018.12.049).

(c) 2018 Elsevier Ltd

This manuscript version is made available under the CC-BY-NC-ND 3.0 license http://creativecommons.org/licenses/by-nc-nd/3.0/

Landres, P.B., Morgan, P., Swanson, F.J., 1999. Overview of the use of natural variability concepts in managing ecological systems. Ecol. Appl. 9(4), 1179-1188.

Lindsey, C.R., Neupane, G., Spycher, N., Fairley, J.P., Dobson, P., Wood, T., McLing, T., Conrad, M., 2018. Cluster analysis as a tool for evaluating the exploration potential of known geothermal resource areas. Geothermics 72, 358-370.

Lobera, G., Besné, P., Vericat, D., López-Tarazón, J.A., Tena, A., Aristi, I., Díez, J.R., Ibisate, A., Larrañaga, A., Elosegi, A., Batalla, R.J., 2015. Geomorphic status of regulated rivers in the Iberian Peninsula. Sci. Total Environ. 508, 101-114.

Lorenzo-Lacruz, J., Vicente-Serrano, S.M., López-Moreno, J.I., Morán-Tejeda, E., Zabalza, J., 2012. Recent trends in Iberian streamflows (1945-2005). J. Hydrol. 414, 463-475.

Ludwig, W., Dumont, E., Meybeck, M., Heussner, S., 2009. River discharges of water and nutrients to the Mediterranean and Black Sea: major drivers for ecosystem changes during past and future decades. Progr. Oceanogr. 80(3), 199-217.

MacQueen, J.B., 1967. Some Methods for classification and Analysis of Multivariate Observations. Proceedings of 5th Berkeley Symposium on Mathematical Statistics and Probability. 1. University of California Press. 281-297.

Magilligan, F.J., Nislow, K.H., 2005. Changes in hydrologic regime by dams. Geomorphology 71(1-2), 61-78.

Mahoney, J.M., Rood, S.B., 1998. Streamflow requirements for cottonwood seedling recruitmentan integrative model. Wetlands 18(4), 634-645.

Marchetti, M P., Moyle, P.B., 2001. Effects of flow regime on fish assemblages in a regulated California stream. Ecol. Appl. 11(2), 530-539.

McManamay, R.A., 2014. Quantifying and generalizing hydrologic responses to dam regulation using a statistical modeling approach. J. Hydrol. 519, 1278-1296.

McManamay, R.A., Orth, D.J., Dolloff, C.A., 2012. Revisiting the homogenization of dammed rivers in the southeastern US. J. Hydrol. 424, 217-237. 
This document is the Accepted Manuscript version of a Published Work that appeared in final form in:

García de Jalón S., González del Tánago M., García de Jalón D. 2019. A new approach for assessing natural patterns of flow variability and hydrological alterations: The case of the Spanish rivers. JOURNAL OF ENVIRONMENTAL MANAGEMENT. 233. 200-210. DOI (10.1016/j.jenvman.2018.12.049).

(c) 2018 Elsevier Ltd

This manuscript version is made available under the CC-BY-NC-ND 3.0 license http://creativecommons.org/licenses/by-nc-nd/3.0/

MMA (Ministerio Medio Ambiente), 2006. Inventario de Presas Españolas. Publicaciones Ministerio de Medio Ambiente, Madrid, Spain.

Morán-Tejeda, E., López-Moreno, J.I., Ceballos-Barbancho, A., Vicente-Serrano, S.M., 2011. River regimes and recent hydrological changes in the Duero basin (Spain). J. Hydrol. 404(3-4), 241258.

Moyle, P.B., Mount, J.F., 2007. Homogenous rivers, homogenous faunas. Proceedings of the National Academy of Sciences 104(14), 5711-5712.

Naiman, R.J., Latterell, J.J., Pettit, N.E., Olden, J.D., 2008. Flow variability and the biophysical vitality of river systems. C. R. Geosci. 340(9-10), 629-643.

Olden, J.D., Kennard, M.J., Pusey, B.J., 2012. A framework for hydrologic classification with a review of methodologies and applications in ecohydrology. Ecohydrology 5(4), 503-518.

Olden, J.D., Poff, N.L., 2003. Redundancy and the choice of hydrologic indices for characterizing streamflow regimes. River Res. Appl. 19(2), 101-121.

Peñas, F.J., Barquín, J., Álvarez, C., 2016. Sources of variation in hydrological classifications: Time scale, flow series origin and classification procedure. J. Hydrol. 538, 487-499.

Poff N.L., Allan J.D., Bain M.B., Karr J.R., Prestegaard K.L., Richter, B.D., Sparks, R.E., Stromberg, J.C., 1997. The natural flow regime. BioScience 47(11), 769-784.

Poff, N.L., Olden, J.D., Merritt, D.M., Pepin, D.M., 2007. Homogenization of regional river dynamics by dams and global biodiversity implications. Proceedings of the National Academy of Sciences 104(14), 5732-5737.

Poff, N.L., Richter, B.D., Arthington, A.H., Bunn, S.E., Naiman, R.J., Kendy, E., Acreman, M., Apse, C., Bledsoe, B.P., Freeman, M.C., Henriksen, J., Jacobson, R.B., Kennen, J.G., Merrit, D.M., O'Keeffe, J.H., Olden, J.D., Rogers, K., Tharme, R.E. Warner, A., 2010. The ecological limits of hydrologic alteration (ELOHA): a new framework for developing regional environmental flow standards. Freshwater Biol. 55(1), 147-170. 
This document is the Accepted Manuscript version of a Published Work that appeared in final form in:

García de Jalón S., González del Tánago M., García de Jalón D. 2019. A new approach for assessing natural patterns of flow variability and hydrological alterations: The case of the Spanish rivers. JOURNAL OF ENVIRONMENTAL MANAGEMENT. 233. 200-210. DOI (10.1016/j.jenvman.2018.12.049).

(c) 2018 Elsevier Ltd

This manuscript version is made available under the CC-BY-NC-ND 3.0 license http://creativecommons.org/licenses/by-nc-nd/3.0/

Poff, N.L., Zimmerman, J.K., 2010. Ecological responses to altered flow regimes: a literature review to inform the science and management of environmental flows. Freshwater Biol. 55(1), 194205.

$R$ Core Team and contributors worldwide, 2013. Stats. $R$ package version 3.5.0. Available at: https://stat.ethz.ch/R-manual/R-devel/library/stats/html/hclust.html.

R Core Team, 2013. R: A language and environment for statistical computing. R Foundation for Statistical Computing, Vienna, Austria. Available at: http://www.R-project.org/.

Rencher, A.C., Christensen, W.F., 2012. Methods of Multivariate Analysis. John Wiley \& Sons, Inc., Hoboken, NJ.

Richter, B.D., 2010. Re-thinking environmental flows: from allocations and reserves to sustainability boundaries. River Res. Appl. 26(8), 1052-1063.

Richter, B.D., Baumgartner, J.V., Powell, J., Braun, D.P., 1996. A method for assessing hydrologic alteration within ecosystems. Conserv. Biol. 10(4), 1163-1174.

Richter, B.D., Davis, M.M., Apse, C., Konrad, C., 2012. A presumptive standard for environmental flow protection. River Res. Appl. 28(8), 1312-1321.

Skoulikidis, N.T., Sabater, S., Datry, T., Morais, M.M., Buffagni, A., Dörflinger, G., Zogaris, S., SánchezMontoya, M., Bonada, N., Kalogianni, E., Rosado, J., Vardakas, L., De Girolamo, A.M. Tockner, K., 2017. Non-perennial Mediterranean rivers in Europe: status, pressures, and challenges for research and management. Sci. Total Environ. 577, 1-18.

Snelder, T.H., Lamouroux, N., Leathwick, J.R., Pella, H., Sauquet, E., Shankar, U., 2009. Predictive mapping of the natural flow regimes of France. J. Hydrol. 373(1-2), 57-67.

Solans, M.A., Poff, N.L., 2013. Classification of natural flow regimes in the Ebro Basin (Spain) by using a wide range of hydrologic parameters. River Res. Appl. 29(9), 1147-1163.

Stromberg, J.C., Lite, S.J., Dixon, M.D., 2010. Effects of stream flow patterns on riparian vegetation of a semiarid river: implications for a changing climate. River Res. Appl. 26(6), 712-729. 
This document is the Accepted Manuscript version of a Published Work that appeared in final form in:

García de Jalón S., González del Tánago M., García de Jalón D. 2019. A new approach for assessing natural patterns of flow variability and hydrological alterations: The case of the Spanish rivers. JOURNAL OF ENVIRONMENTAL MANAGEMENT. 233. 200-210. DOI (10.1016/j.jenvman.2018.12.049).

(C) 2018 Elsevier Ltd

This manuscript version is made available under the CC-BY-NC-ND 3.0 license http://creativecommons.org/licenses/by-nc-nd/3.0/

Tockner, K., Uehlinger, U., Robinson, C.T., Tonolla, D., Siber, R., Peter, F.D., 2009. Introduction to European rivers. In: Tockner, K., Uehlinger, U., Robsinson, C.T. (Eds.), Rivers of Europe. Academic Press, London, pp. 1-23.

Vörösmarty, C.J., McIntyre, P.B., Gessner, M.O., Dudgeon, D., Prusevich, A., Green, P., Glidden, S., Bunn, S.E., Sullivan, C.A., Reidy Liermann, C., Davies, P.M., 2010. Global threats to human water security and river biodiversity. Nature 467(7315), 555.

WATECO, 2003. Common implementation strategy for the Water Framework Directive. Guidance Document No 1. Economics and the Environment. The implementation challenge of the Water Framework Directive, Working Group 2.6 WATECO, European Communities, Luxembourg.

Wohl, E., 2012. Identifying and mitigating dam-induced declines in river health: three case studies from the western United States. Int. J. Sediment Res. 27(3), 271-287.

Yarnell, S.M., Petts, G.E., Schmidt, J.C., Whipple, A.A., Beller, E.E., Dahm, C.N., Goodwin, P., Viers, J.H., 2015. Functional flows in modified riverscapes: Hydrographs, habitats and opportunities. BioScience 65(10), 963-972. 
This document is the Accepted Manuscript version of a Published Work that appeared in final form in:

García de Jalón S., González del Tánago M., García de Jalón D. 2019. A new approach for assessing natural patterns of flow variability and hydrological alterations: The case of the Spanish rivers. JOURNAL OF ENVIRONMENTAL MANAGEMENT. 233. 200-210. DOI (10.1016/j.jenvman.2018.12.049).

(c) 2018 Elsevier Ltd

This manuscript version is made available under the CC-BY-NC-ND 3.0 license http://creativecommons.org/licenses/by-nc-nd/3.0/

Table 1. Mean (and standard deviation) for low-impact, high-impact and total-impact in constant highintensity, constant low-intensity and seasonal rivers and results of MANOVA, ANOVA and Tukey's HSD tests used to detect differences among the three clusters of rivers.

\begin{tabular}{llll}
\hline \multirow{2}{*}{ Cluster } & $\begin{array}{l}\text { Low Impact } \\
\text { Mean (SD) }\end{array}$ & $\begin{array}{l}\text { High Impact } \\
\text { Mean (SD) }\end{array}$ & $\begin{array}{l}\text { Total Impact } \\
\text { Mean (SD) }\end{array}$ \\
\hline Constant high-intensity & $0.31(0.38)$ & $0.17(0.31)$ & $0.49(0.37)$ \\
Constant low-intensity & $0.09(0.2)$ & $0.04(0.12)$ & $0.12(0.22)$ \\
Seasonal & $0.08(0.19)$ & $0.19(0.31)$ & $0.27(0.31)$ \\
\hline MANOVA $(P)$ & $<0.001$ & $<0.001$ & \\
\hline ANOVA $(P)$ & $<0.001$ & $<0.001$ & $<0.001$ \\
\hline Tukey's HSD $(P)$ & & & \\
Constant low-intensity-constant high-intensity & $<0.001$ & $<0.001$ & $<0.001$ \\
Seasonal-constant high-intensity & $<0.001$ & $<0.001$ & $<0.001$ \\
Seasonal-constant low-intensity & 0.002 & $<0.001$ & $<0.001$ \\
\hline
\end{tabular}


This document is the Accepted Manuscript version of a Published Work that appeared in final form in:

García de Jalón S., González del Tánago M., García de Jalón D. 2019. A new approach for assessing natural patterns of flow variability and hydrological alterations: The case of the Spanish rivers. JOURNAL OF ENVIRONMENTAL MANAGEMENT. 233. 200-210. DOI (10.1016/j.jenvman.2018.12.049).

(C) 2018 Elsevier Ltd

This manuscript version is made available under the CC-BY-NC-ND 3.0 license http://creativecommons.org/licenses/by-nc-nd/3.0/

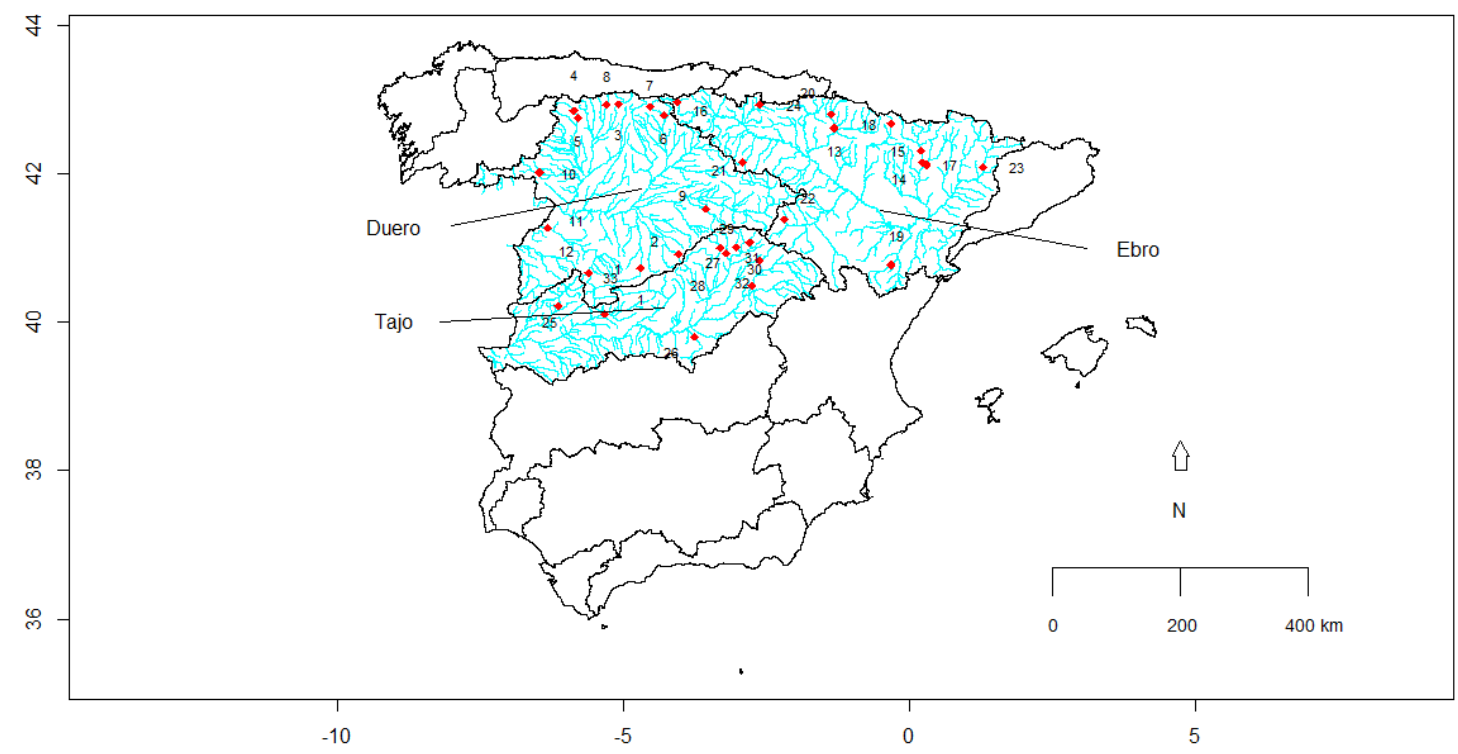

Figure 1. Location of the studied rivers in the Duero, Ebro and Tajo basins in Spain. See identification numbers (ID) in Table 1 to see river and reservoir names and characteristics. 
This document is the Accepted Manuscript version of a Published Work that appeared in final form in:

García de Jalón S., González del Tánago M., García de Jalón D. 2019. A new approach for assessing natural patterns of flow variability and hydrological alterations: The case of the Spanish rivers. JOURNAL OF ENVIRONMENTAL MANAGEMENT. 233. 200-210. DOI (10.1016/j.jenvman.2018.12.049).

\section{(c) 2018 Elsevier Ltd}

This manuscript version is made available under the CC-BY-NC-ND 3.0 license http://creativecommons.org/licenses/by-nc-nd/3.0/
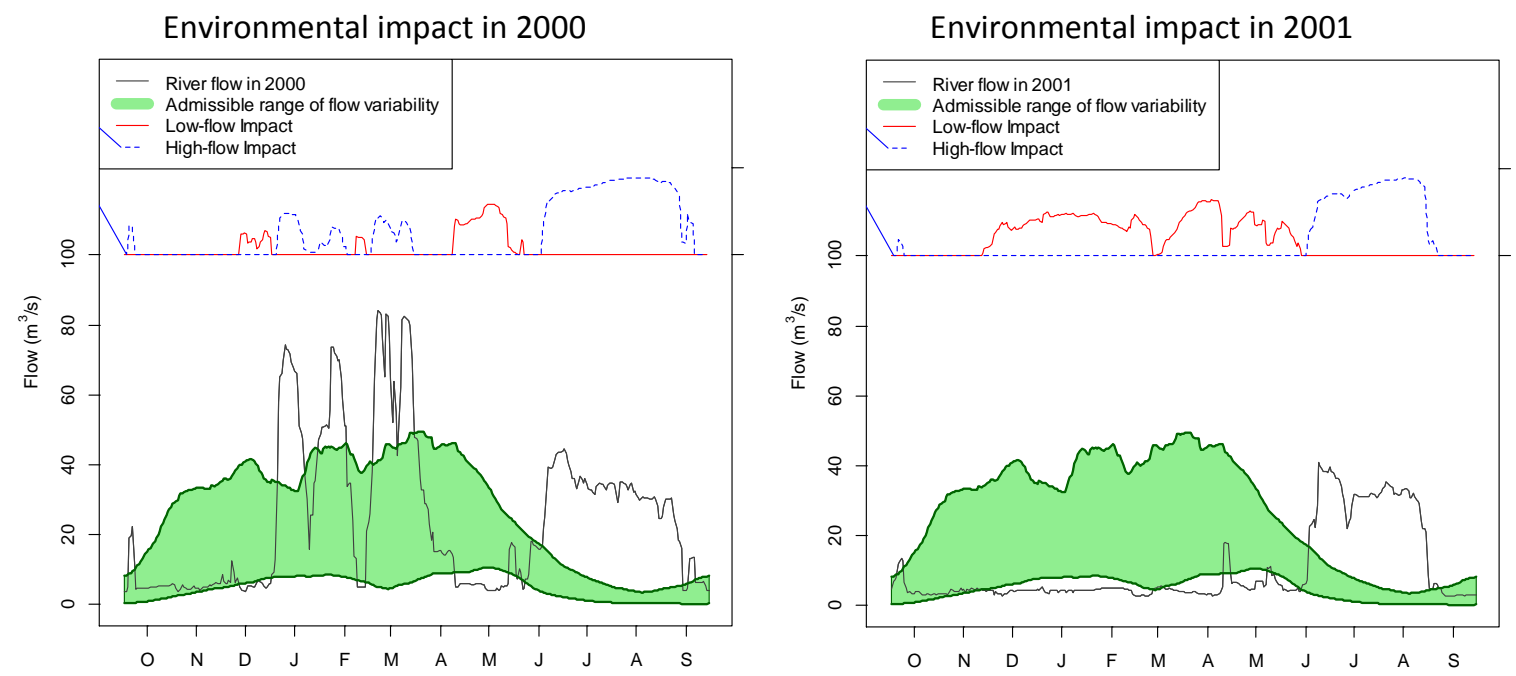

Figure 2. Example of the estimated admissible area of flow variability in the Luna River (Spain) (light-green area) and low and high impacts of flow regulation in 2000 (left graph) and 2001 (right graph). The lower graphs show the circulating flows during the respective years (black line) over the estimated reference admissible range of flow variability. The upper graphs show the estimated low-flow (dark-green solid line) and high-flow (blue dashed line) impacts calculated as the deviation from the reference admissible area. 
This document is the Accepted Manuscript version of a Published Work that appeared in final form in:

García de Jalón S., González del Tánago M., García de Jalón D. 2019. A new approach for assessing natural patterns of flow variability and hydrological alterations: The case of the Spanish rivers. JOURNAL OF ENVIRONMENTAL MANAGEMENT. 233. 200-210. DOI (10.1016/j.jenvman.2018.12.049).

(C) 2018 Elsevier Ltd

This manuscript version is made available under the CC-BY-NC-ND 3.0 license http://creativecommons.org/licenses/by-nc-nd/3.0/

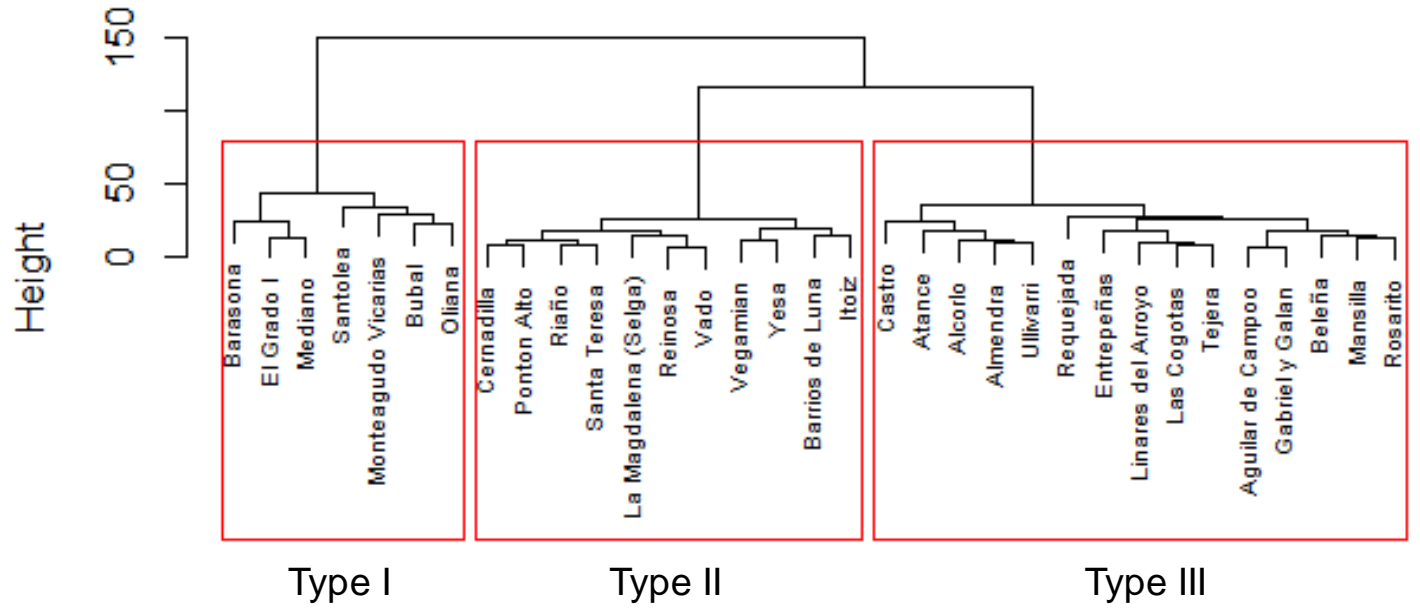

Figure 3. Dendrogram of the hierarchical cluster analysis using the 'Ward' method, according to the estimated admissible range of flow variability (pre-dam period). 
This document is the Accepted Manuscript version of a Published Work that appeared in final form in:

García de Jalón S., González del Tánago M., García de Jalón D. 2019. A new approach for assessing natural patterns of flow variability and hydrological alterations: The case of the Spanish rivers. JOURNAL OF ENVIRONMENTAL MANAGEMENT. 233. 200-210. DOI (10.1016/j.jenvman.2018.12.049).

(C) 2018 Elsevier Ltd

This manuscript version is made available under the CC-BY-NC-ND 3.0 license http://creativecommons.org/licenses/by-nc-nd/3.0/

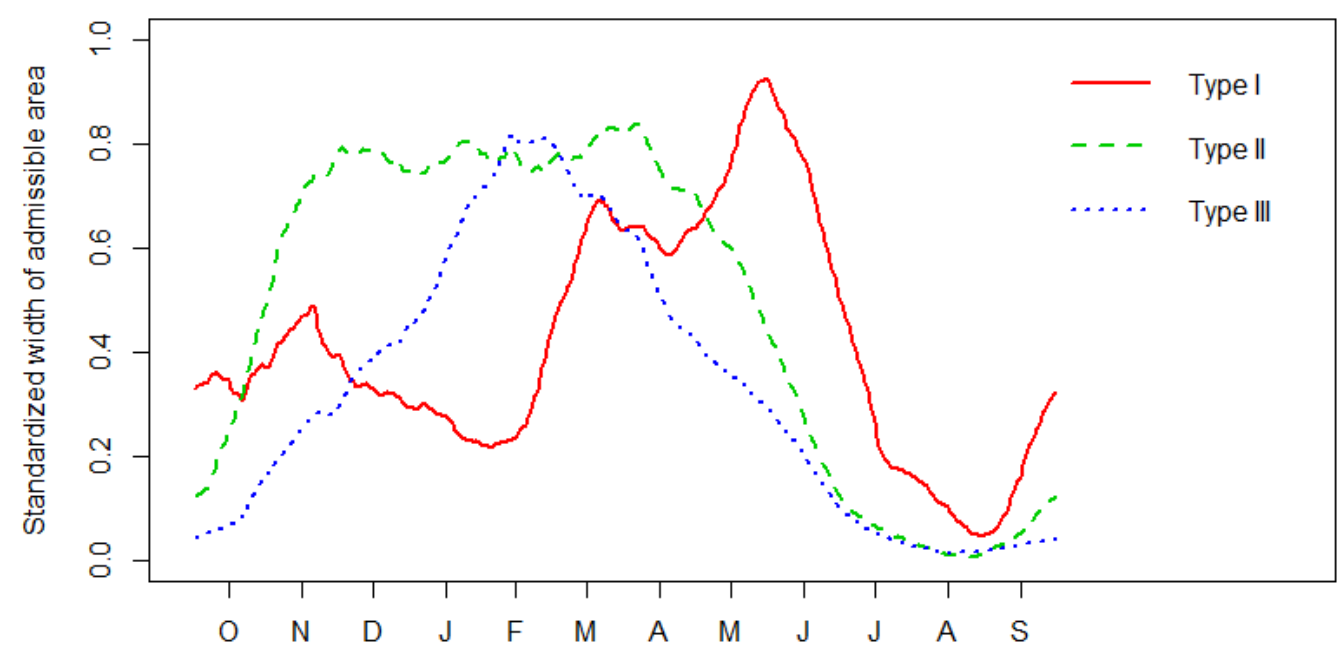

Figure 4. Standardized admissible area of flows (difference between the upper and lower limit of the admissible area) in the identified types of rivers according to their natural flow regimes shown in Figure 3. 
This document is the Accepted Manuscript version of a Published Work that appeared in final form in:

García de Jalón S., González del Tánago M., García de Jalón D. 2019. A new approach for assessing natural patterns of flow variability and hydrological alterations: The case of the Spanish rivers. JOURNAL OF ENVIRONMENTAL MANAGEMENT. 233. 200-210. DOI (10.1016/j.jenvman.2018.12.049).

(C) 2018 Elsevier Ltd

This manuscript version is made available under the CC-BY-NC-ND 3.0 license http://creativecommons.org/licenses/by-nc-nd/3.0/
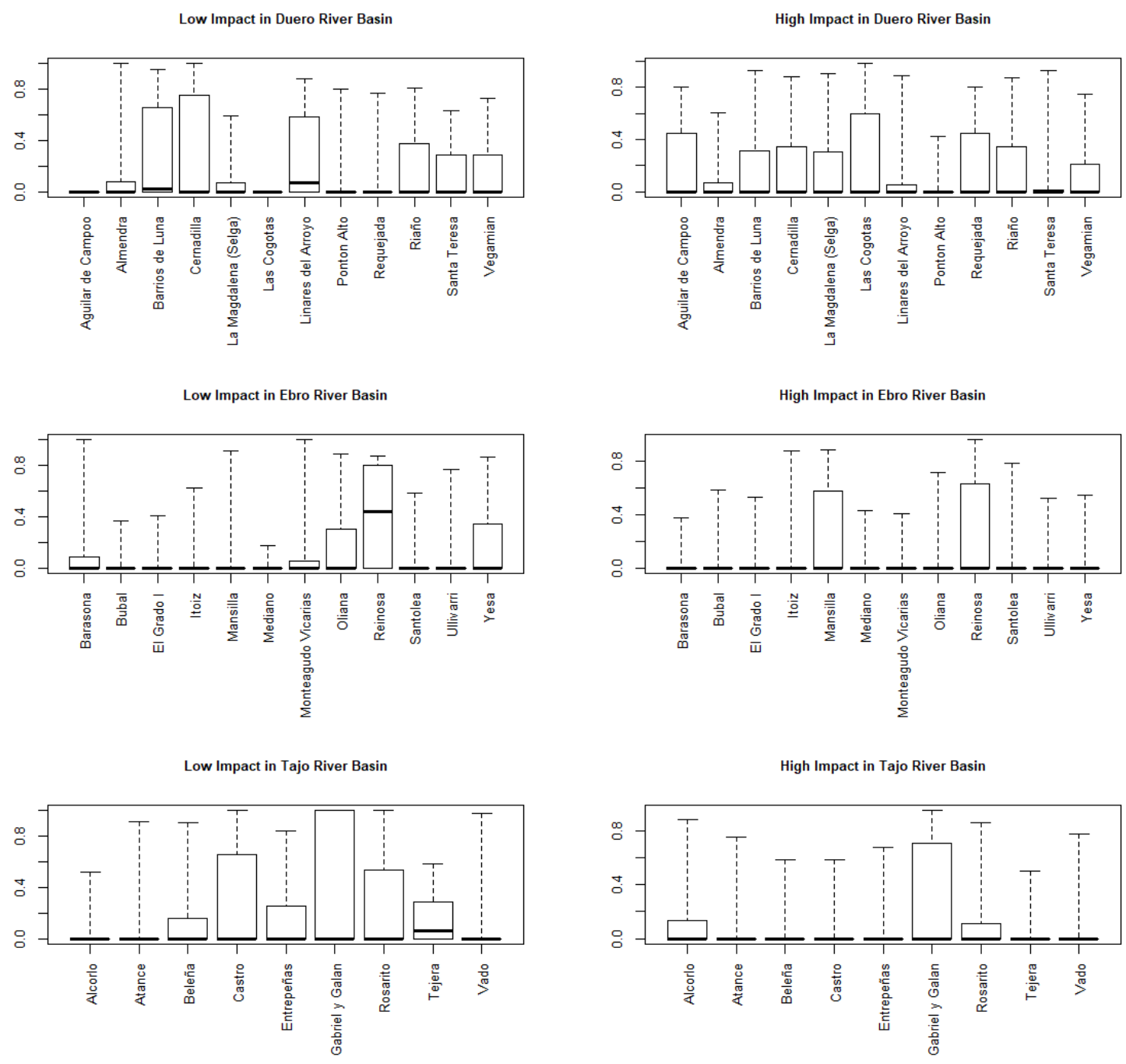

Figure 5. Daily environmental impact values from flow regulation in rivers in the Duero, Ebro and Tajo basins during the period 2000-2010. For the Itioiz and Atance Rivers, the flow impact was estimated from 2003 to 2010 and from 2001 to 2010, respectively. The bottom and top whiskers indicate minimum and maximum values, respectively, and the bottom and top line of the boxes indicate values of percentile 25 and percentile 75 , respectively, and lines within boxes indicate median values. 
This document is the Accepted Manuscript version of a Published Work that appeared in final form in:

García de Jalón S., González del Tánago M., García de Jalón D. 2019. A new approach for assessing natural patterns of flow variability and hydrological alterations: The case of the Spanish rivers. JOURNAL OF ENVIRONMENTAL MANAGEMENT. 233. 200-210. DOI (10.1016/j.jenvman.2018.12.049).

(C) 2018 Elsevier Ltd

This manuscript version is made available under the CC-BY-NC-ND 3.0 license http://creativecommons.org/licenses/by-nc-nd/3.0/ 
This document is the Accepted Manuscript version of a Published Work that appeared in final form in:

García de Jalón S., González del Tánago M., García de Jalón D. 2019. A new approach for assessing natural patterns of flow variability and hydrological alterations: The case of the Spanish rivers. JOURNAL OF ENVIRONMENTAL MANAGEMENT. 233. 200-210. DOI (10.1016/j.jenvman.2018.12.049).

(C) 2018 Elsevier Ltd

This manuscript version is made available under the CC-BY-NC-ND 3.0 license http://creativecommons.org/licenses/by-nc-nd/3.0/

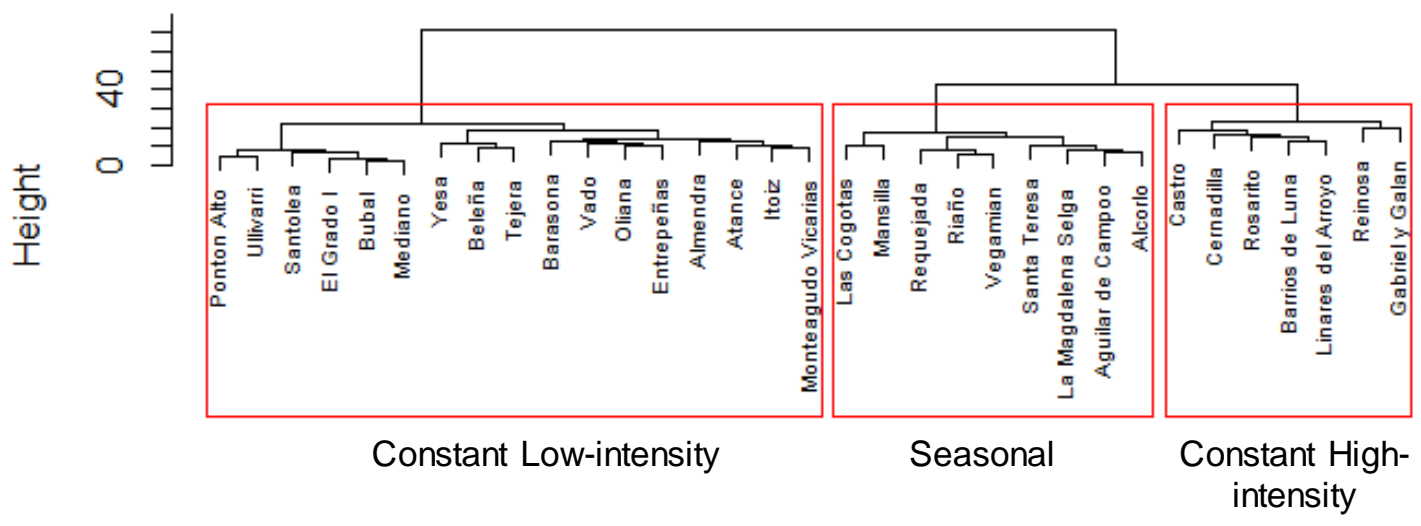

Figure 6. Dendrogram of the hierarchical cluster analysis using the 'Ward' method, according to the estimated daily flow regulation impacts in 2000-2010 (post-dam period). 
This document is the Accepted Manuscript version of a Published Work that appeared in final form in:

García de Jalón S., González del Tánago M., García de Jalón D. 2019. A new approach for assessing natural patterns of flow variability and hydrological alterations: The case of the Spanish rivers. JOURNAL OF ENVIRONMENTAL MANAGEMENT. 233. 200-210. DOI (10.1016/j.jenvman.2018.12.049).

\section{(c) 2018 Elsevier Ltd}

This manuscript version is made available under the CC-BY-NC-ND 3.0 license http://creativecommons.org/licenses/by-nc-nd/3.0/
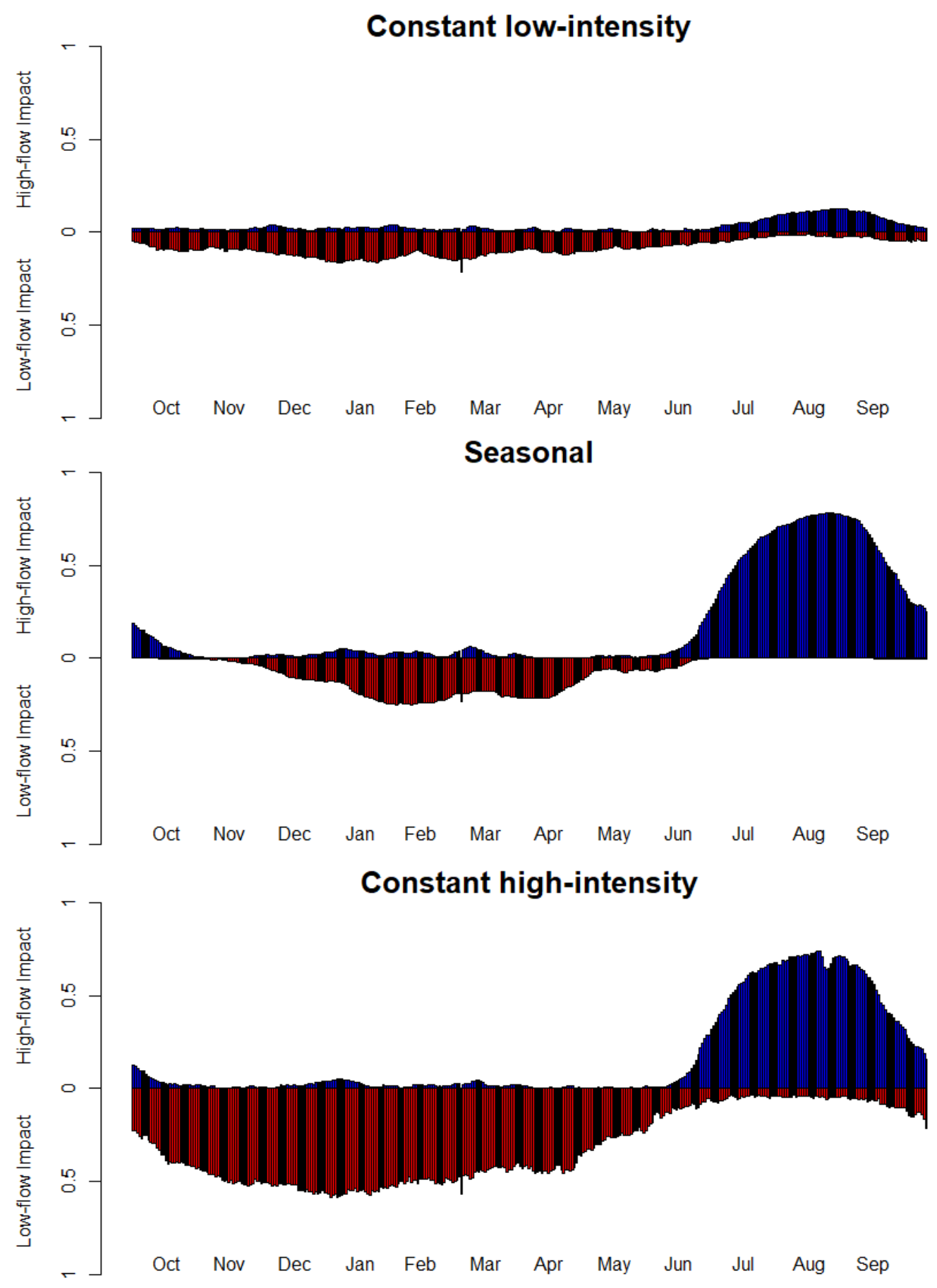
This document is the Accepted Manuscript version of a Published Work that appeared in final form in:

García de Jalón S., González del Tánago M., García de Jalón D. 2019. A new approach for assessing natural patterns of flow variability and hydrological alterations: The case of the Spanish rivers. JOURNAL OF ENVIRONMENTAL MANAGEMENT. 233. 200-210. DOI (10.1016/j.jenvman.2018.12.049).

(C) 2018 Elsevier Ltd

This manuscript version is made available under the CC-BY-NC-ND 3.0 license http://creativecommons.org/licenses/by-nc-nd/3.0/

Figure 7. Daily impacts in rivers with constant and low-intensity impacts, rivers with seasonal impacts and rivers with constant and high-intensity impacts. Red and downward-facing bars indicate low-flow impacts and blue and upward-facing bars indicate high-flow impacts. 